\title{
Isolation, Identification and Molecular Detection of Brucella spp., in Cattle and Buffaloes
}

\author{
Sai Lakshmi Kanth Katrapati, N.S. Sharma* and Paviter Kaur \\ Department of Veterinary Microbiology, Guru Angad Dev Veterinary and Animal Sciences \\ University, Ludhiana, Punjab, India \\ *Corresponding author
}

\section{A B S T R A C T}

\section{Keywords \\ Isolation, Molecular Detection, Brucella spp., Buffaloes \\ Article Info \\ Accepted: \\ 04 August 2018 \\ Available Online: \\ 10 September 2018}

The present study was carried out for the isolation, identification and molecular characterization of Brucella species. A total of 50 samples were collected from cattle and buffalo suffering from abortions and other reproductive disorders in and around Ludhiana, Punjab. Out of the 50 samples of fetal stomach contents (25), uterine discharges (10), vaginal mucus (8) and placenta (7) processed for isolation of Brucella of which a total of four isolate were obtained and identified biochemically. All the 4 isolates were typed as biotype 1. DNA was extracted from the solates and subjected to PCR using B4/B5 primer pair. All the isolates were positive by PCR and an amplicon size of $223 \mathrm{bp}$ was obtained.

\section{Introduction}

Brucellosis is a highly contagious and important zoonotic disease caused by Brucella spp. They are small, gram negative, nonmotile, non-spore forming, facultative intracellular coccobacilli.

Transmission of the organism occurs mainly through contact with placenta, fetus, fetal fluids and vaginal discharges from an infected animal. Clinically, the disease is characterized by abortion in the third trimester of pregnancy. Infections may also cause stillborn or weak calves, retained placentas, reduced milk yield and orchitis and epididymitis in males. Confirmation in clinically affected animals is done by isolation and identification of the organism from aborted foetus, foetal membranes and vaginal mucus.

Current paper deals with isolation, identification and molecular detection of Brucella isolated from samples of aborted foetuses and maternal contents.

\section{Materials and Methods}

Samples $(\mathrm{n}=50)$ comprising foetal stomach contents, uterine discharges, vaginal mucus, placenta from cattle and buffalo suffering from abortions and other reproductive disorders in and around Ludhiana, Punjab were collected. 


\section{Isolation and identification}

The samples were inoculated on BSM (Brucella specific medium). The inoculated plates were incubated microaerophilically at $37^{\circ} \mathrm{C}$ under $5-10 \% \mathrm{CO}_{2}$ for up to $3-5$ days and were observed for growth. The isolates were identified based on the morphology, culture characteristics, various biochemical tests like oxidase, catalase, $\mathrm{H}_{2} \mathrm{~S}$ production, urease, nitrate reduction and indole, growth in the presence of dyes i.e. thionin ad basic fuchsin.

\section{Molecular detection}

DNA was extracted from the isolates obtained using hot cold lysis method. Confirmation of the Brucella isolates was done by genus specific PCR primers B4/B5 (Baily et al., 1992) (Table 1). The contents and conditions of PCR are given in Table $2 \& 3$ respectively.

\section{Results and Discussion}

Out of the 50 samples collected from cattle (27) and buffalo (23), 4(8\%) isolates of Brucella were obtained. The details of isolation are shown in the table 4 . The isolates were detected on the basis of morphological and cultural characteristics. Brucella colonies were translucent, round, pinpoint, smooth, glistening, 1-2 $\mathrm{mm}$ in diameter, with smooth margins.

On Gram's staining, the isolates were identified as Gram negative, coccobacilli or rods whereas by MZN staining they appeared to be red with blue background. They were non-motile and did not show growth on McConkey's lactose agar (MLA).

All the four isolates were found positive for catalase, oxidase, urease, $\mathrm{H}_{2} \mathrm{~S}$ production and nitrate reduction test whereas all the isolates were negative for indole test (Table 5) and typed as biotype 1. The extracted DNA subjected to PCR revealed an Amplicon size of $223 \mathrm{bp}$ in positive control as well as in all the four isolates (Fig. 1).

Out of the 50 samples collected 4(8\%) isolates of Brucella were obtained. The current study is in agreement with earlier findings which reported $4 \%$ to $8 \%$ overall isolation rate of Brucella spp., (Ghodasara, 2008; Kanani, 2007) However, in contrast to these findings, isolation rate between $20 \%$ and $39 \%$ has been reported by Das et al., 1990 and Pal and Jain, 1985. All isolates were oxidase and catalase positive as in corroboration with observations of Shome et al., (1999) whereas, Piccininno et al., (1978) identified one B. abortus that it was oxidase negative.

The four isolates of $B$. abortus grew in the presence of basic fuchsin $(20 \mu \mathrm{g} / \mathrm{ml})$ but not in the presence of thionin $(20 \mu \mathrm{g} / \mathrm{ml})$ and hence were typed as biotype 1 . The results are in accordance with the findings of Shahzad et al., (2014) who detected B. abortus biovar 1 from all the 30 isolates obtained. In contrary, Verma et al., (2000) isolated B. abortus biotype 3 from two of seven aborted cows. Holstein Friesian, crossbreds and indigenous breeds of cattle and mixed and Murrah breeds of buffaloes in the age groups of 4-6 and 7-9 were taken into study of which Indigenous cow breed and Murrah breed of buffaloes were found to be most susceptible to brucellosis. Brucellosis in animals in the age group of 4-6 yrs was found to be more prevalent.

DNA was extracted from reference $B$. abortus S19 and from the suspected Brucella isolates.

The extracted DNA was subjected to PCR using Brucella genus specific primer pair B4/B5 targeting bcsp31 gene (Baily et al., 1992). Amplicon size of 223 bp was detected in positive control as well as in all the four isolates (Fig. 1). 
Table.1 Sequence of primers used for detection of genus Brucella

\begin{tabular}{|c|c|c|c|c|}
\hline $\begin{array}{c}\text { Name of the } \\
\text { primers }\end{array}$ & Gene & Sequence (5'-3') & $\begin{array}{l}\text { Size of the } \\
\text { amplified } \\
\text { product }\end{array}$ & Reference \\
\hline B4 (F) & \multirow[t]{2}{*}{ bcsp31 } & TGG CTC GGT TGC CAA TAT CAA & \multirow[t]{2}{*}{223 bp } & \multirow{2}{*}{$\begin{array}{c}\text { Baily et } \\
\text { al (1992) }\end{array}$} \\
\hline B5 (R) & & CGC GCT TGC CTT TCA GGT CTG & & \\
\hline
\end{tabular}

Table.2 Brucella $\mathrm{PCR}$ reaction mixture for B4/B5 primer pair

\begin{tabular}{|c|l|l|c|} 
S. No. & \multicolumn{1}{|c|}{ PCR components } & \multicolumn{1}{c|}{$\begin{array}{c}\text { Required } \\
\text { concentration }\end{array}$} & Amount $(\boldsymbol{\mu l})$ \\
\hline $\mathbf{1}$ & $\mathrm{H}_{2} \mathrm{O}(\mathrm{PCR}$ grade) & $\mathrm{Up}$ to $25 \mu \mathrm{l}$ & 14.3 \\
\hline $\mathbf{2}$ & $\mathrm{PCR}$ Buffer $(10 \mathrm{X})$ & $1 \mathrm{X}$ & 2.5 \\
\hline $\mathbf{3}$ & $\mathrm{MgCl}_{2}(25 \mathrm{mM})$ & $1.5 \mathrm{mM}$ & 1.5 \\
\hline $\mathbf{4}$ & dNTPs $(10 \mathrm{mM})$ & $200 \mu \mathrm{M}$ & 0.5 \\
\hline $\mathbf{5}$ & Primers $(40 \mathrm{pmol} / \mu \mathrm{l}$ each) & $20 \mathrm{pmol}$ each & $0.5+0.5$ \\
\hline $\mathbf{6}$ & Taq $(5 \mathrm{U} / \mu \mathrm{l})$ & $1 \mathrm{U}$ & 0.2 \\
\hline $\mathbf{7}$ & DNA template & $\sim 100 \mathrm{ng}$ & 5.0 \\
\hline $\mathbf{8}$ & & & $\mathbf{2 5}$ \\
\hline
\end{tabular}

Table.3 Brucella PCR program by using B4/B5 primer pair

\begin{tabular}{|c|l|c|c|c|}
\hline Stage & \multicolumn{1}{|c|}{ Step } & Temperature $\left({ }^{\circ} \mathbf{C}\right)$ & Duration & No. of cycles \\
\hline $\mathbf{1}$ & Initial denaturation & 94 & $5 \mathrm{~min}$ & 1 \\
\hline $\mathbf{2}$ & Denaturation & 94 & $60 \mathrm{~s}$ & 35 \\
& Annealing & 65 & $60 \mathrm{~s}$ & \\
\hline $\mathbf{3}$ & Extension & 72 & $60 \mathrm{~s}$ & \\
& Final extension & 72 & $10 \mathrm{~min}$ & 1 \\
\hline
\end{tabular}

Table.4 Isolation of Brucella from different samples

\begin{tabular}{|c|c|c|c|c|}
\hline \multirow[t]{2}{*}{ Type of Sample } & \multicolumn{2}{|c|}{ Cattle } & \multicolumn{2}{|c|}{ Buffaloes } \\
\hline & $\begin{array}{c}\text { No. of } \\
\text { samples } \\
\text { processed }\end{array}$ & $\begin{array}{l}\text { No. of samples } \\
\text { positive for } \\
\text { isolation }\end{array}$ & $\begin{array}{c}\text { No. of } \\
\text { samples } \\
\text { processed }\end{array}$ & $\begin{array}{l}\text { No. of samples } \\
\text { positive for } \\
\text { isolation }\end{array}$ \\
\hline $\begin{array}{l}\text { Foetal stomach } \\
\text { content }\end{array}$ & 11 & 02 & 14 & 01 \\
\hline Uterine discharge & 7 & - & 3 & - \\
\hline $\begin{array}{l}\text { Vaginal mucus and } \\
\text { Vaginal discharge }\end{array}$ & 5 & - & 3 & - \\
\hline Placenta & 4 & 1 & 3 & - \\
\hline Total & 27 & 03 & 23 & 01 \\
\hline
\end{tabular}


Table.5 Biochemical characterization of Brucella spp.

\begin{tabular}{|c|c|c|c|c|c|c|c|c|c|c|c|}
\hline \multirow{2}{*}{$\begin{array}{l}\text { S. } \\
\text { No }\end{array}$} & \multirow[t]{2}{*}{ Isolate no } & \multirow[t]{2}{*}{ Oxidase } & \multirow[t]{2}{*}{ Catalase } & \multirow{2}{*}{$\begin{array}{c}\mathrm{H}_{2} \mathrm{~S} \\
\text { (TSI) }\end{array}$} & \multirow[t]{2}{*}{ Urease } & \multirow{2}{*}{$\begin{array}{l}\text { Nitrate } \\
\text { reduction }\end{array}$} & \multirow[t]{2}{*}{ Indole } & \multirow{2}{*}{$\begin{array}{l}\text { Agglutinatic } \\
\text { n with } \\
\text { antiserum }\end{array}$} & \multicolumn{3}{|c|}{ Growth in the presence of dyes } \\
\hline & & & & & & & & & $\begin{array}{l}\text { Thionin } \\
20 \mu \mathrm{g} / \mathrm{ml}\end{array}$ & $\begin{array}{c}\text { Basic } \\
\text { fuschin } \\
20 \mu \mathrm{g} / \mathrm{ml}\end{array}$ & Biotype \\
\hline 1 & $\mathrm{P} 1$ & + & + & + & + & + & - & + & - & + & 1 \\
\hline 2 & $\mathrm{P} 2$ & + & + & + & + & + & _ & + & - & + & 1 \\
\hline 3 & P3 & + & + & + & + & + & - & + & - & + & 1 \\
\hline 4 & $\mathrm{P} 4$ & + & + & + & + & + & - & + & - & + & 1 \\
\hline
\end{tabular}

Fig.1 Gel electrophoresis of PCR amplified fragments from Brucella isolates using B4/B5 primer pair

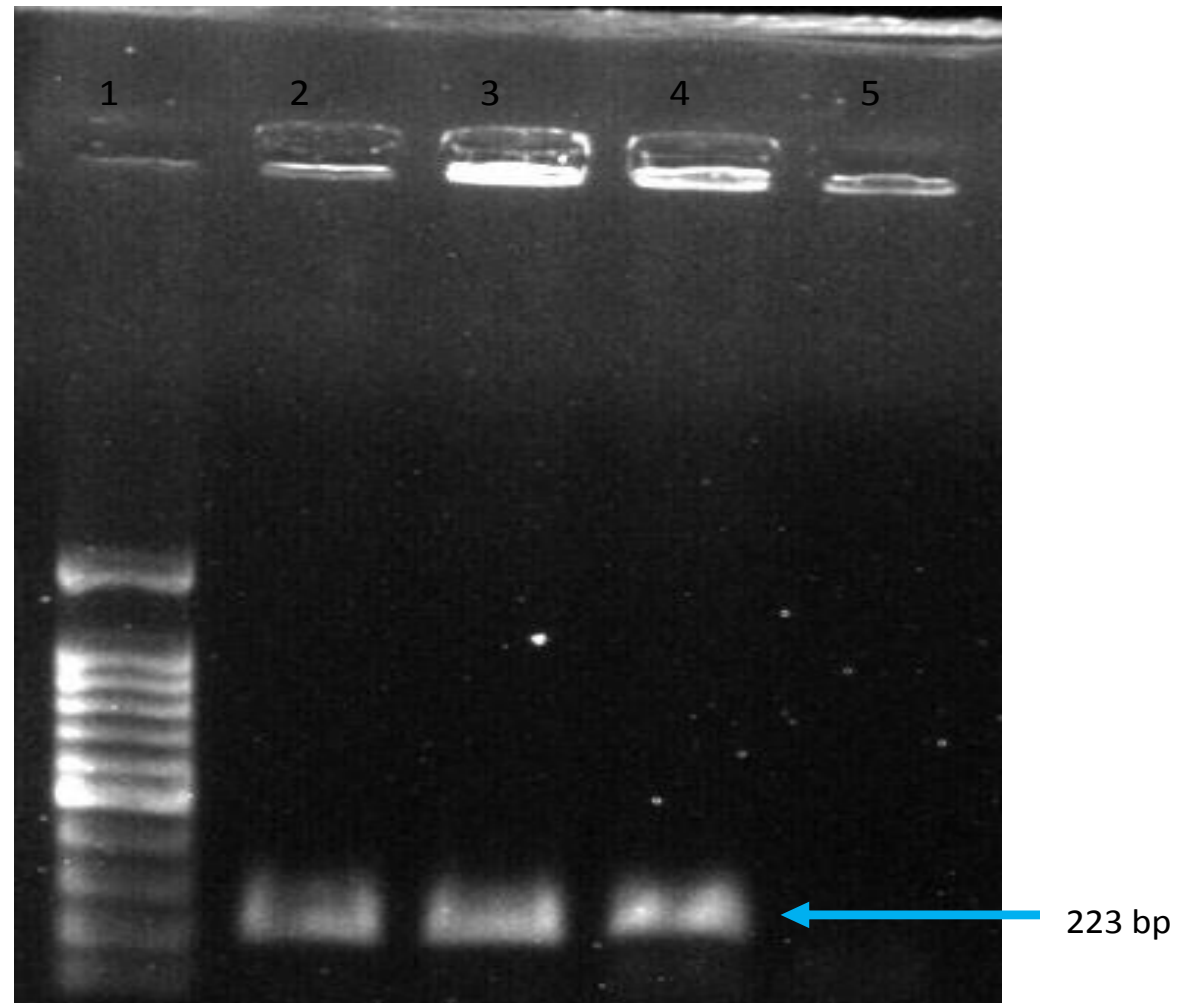

Lane 1: DNA Ladder

Lane 2 \& 3: Brucella field isolates

Lane 4: Positive control

Lane 5: Negative control

Kanani (2007) compared three pairs of primers amplifying three different fragments, a gene encoding a $31 \mathrm{kDa} B$. abortus antigen (primer B4/B5), a sequence 16S rRNA of B. abortus (primer F4/R2) and a gene encoding an omp2 (primer JPF/JPR) by testing 101 semen samples and found that B4/B5 primer pair was more sensitive followed by F4/R2 primer and JPF/JPR primer pair. Similarly, Jung et al., (1998) carried out detection of Brucella by using bcsp31 gene based B4/B5 primer. Navarro et al., (2002) and Varasada (2003) used same primer pair for diagnosis of human brucellosis. 
Based on the study conducted, foetal stomach content was found to be the best sample for isolation of Brucella spp. Indigenous breed of cattle and Murrah breed of buffaloes in the age group of 4-6 yrs were found to be most susceptible to brucellosis. Molecular detection based methods were found to be equally sensitive to isolation.

\section{Acknowledgement}

The authors are grateful to DBT and University authorities for providing the necessary funding for carrying out the research work.

\section{References}

Bailey G G, Krahn J B, Drasar B S and Stoker $N$ G. 1992. Detection of Brucella melitensis and Brucella abortus by DNA amplification. The American journal of tropical medicine and hygeine 95: 27175.

Das V M, Paranjape V L, Corbel M J. 1990. Investigation of brucellosis associated abortion in dairy buffaloes and cows in Bombay. Indian Journal of Animal Sciences 60(10): 1193-1194.

Ghodasara S. 2008. Serological, cultural and molecular characterization of reproductive disorder in various animals and serodetection of Brucella antibody. An M.V.Sc. thesis submitted to A. A. U., Anand

Jung S C, Jung B Y, Woo S R, Cho D H, Kim J Y, Kim W T, Lee J M, Park Y H and Baek B K. (1998). Development of a PCR assay for the detection of Brucella spp. in bovine semen. Korean Journal of Veterinary Research 38: 345-52.

Kanani A N (2007) Serological, cultural and molecular detection of Brucella infection in breeding bulls. $\mathrm{Ph}$. D. thesis submitted to A. A. U., Anand.

Navarro E, Escribano J, Fernandez J A and Solera J. (2002). Comparison of three different PCR methods for detection of Brucella spp. in human blood samples. FEMS Immunology and Medical Microbiology 34: 147-151.

Pal M. and Jain H S. (1985). Investigation into an outbreak of abortion in buffaloes due to Brucella abortus. The Indian Journal of Animal Research 6: 37-34.

Piccininno G, Ciuchini F, Lillini E and Amaddeo D. 1978. Morphological, biochemical and serological characteristics of a Brucella canis strain, in comparison with Brucella abortus, melitensis and ovis strains. ArchivioVeterinario-Italiano 29(5-6): 149-51.

Shahzad A, Qurban A, Falk M, Iahtasham K, Shamim A, Heinrich N and Syed J. 2014. Isolation and identification of bovine Brucella isolates from Pakistan by biochemical tests and PCR. Tropical Animal Health \& Production 46: 73.

Shome R, Shome B R, Senani S, Saha S K, Padhi M K and Srivastava N. 1999. Isolation and characterization of Brucella abortus from bovines in Andamans. Indian Veterinary Journal 76: 571-73

Varasada, R. N. (2003). Seroprevalence of brucellosis in cattle, buffalo and human being in central Gujarat. A M. V. Sc. thesis, submitted to Gujarat Agricultural University, Sardar Krushinagar, India.

Verma S, Katoch R C, Sharma M and Nigam P. 2000. Abortions and infertility in domestic livestock due to brucellosis in Himachal Pradesh, India. Veterinarski Archives 70(2): 75-82.

\section{How to cite this article:}

Sai Lakshmi Kanth Katrapati, N.S. Sharma and Paviter Kaur. 2018. Isolation, Identification and Molecular Detection of Brucella spp., in Cattle and Buffaloes. Int.J.Curr.Microbiol.App.Sci. 7(09): 401-405. doi: https://doi.org/10.20546/ijcmas.2018.709.049 